REFLECTIONS:

NEUROLOGY AND

THE HUMANITIES

Section Editor

Anne W. McCammon,

MD, FAAN

S. Thomas Carmichael, $\mathrm{MD}, \mathrm{PhD}$

Correspondence to

Dr. Carmichael:

scarmichael@mednet.ulca.edu

\title{
Molecular medicine and the art of brain repair
}

Stroke, traumatic brain injury, and spinal cord injury claim patients in an instant from the ranks of the whole and independent and render them mentally or physically impaired. Once patients with acute diseases of the brain and nervous system are medically stabilized, they embark on neurorehabilitation, which reflects a medical past of longer admissions and deep personal interactions between staff and patients. Because neurorehabilitation stands apart from the trajectory of acute medical illness, its current practice remains a mystery for many physicians.

In the book of shadows

the first page is dark

and the second darker still,

$$
\text { —Linda Pastan, "The Book" }
$$

A trip through the neurorehabilitation unit may be like reading the book of shadows, as these broken people work with therapists to learn the rudiments of gait or haltingly gesture in speech therapy to recapture the spoken word. In the treatment of the brain injured the story starts out darkly. The patient is a shadow: damaged, frightened, and withdrawn.

Father O'Conner had his fourth stroke in summer, the time of year for most of his life when he moved with the migrant farm workers. Up from the desert and through the Imperial and San Joaquin Valleys of California, they followed the harvest of lettuce and melons. Once Father O'Conner advocated for housing and arranged for their families. Now he sits quietly in his room working on the control of his left arm and leg.

Down the hall, John is a 15 -year-old boy who barely survived his heart transplant. After several cardiopulmonary arrests and a prolonged acute hospital course, he is weak from a critical illness myopathy, distractible and inattentive with cognitive dysfunction from the arrests, and angry at his loss of abilities. John is physically and neurologically atrophied, with medical illness magnifying the awkwardness of teenage years.

In the room next to him, Carlos struggles with his new wheelchair. Headstrong and robust, he was a fearless 25 -year-old with a very fast motorcycle. One missed turn took him into a freeway guiderail. Today he is learning the realities of bladder catheterization.
The last room on the unit has 2 sisters, 84-yearold identical twins who have lived together most of their lives. Eddie had a stroke that produced an expressive aphasia. While she struggles to regain control of verbal expression with the speech therapist, in her room she and her sister communicate almost incessantly with gestures, winks, and probably telepathy. Decades of nonverbal communication now convey thoughts and needs.

There are no medicines that promote brain repair. In the neurorehabilitation unit, human touch, the power of emotional connection, and the promise of incremental progress from daily personal engagement are the cornerstones of therapy. Physical therapists grasp patients and hug them to themselves to train transfers from a bed to standing. Occupational therapists hold shoulders in position and train control of the trunk for combing hair or brushing teeth. Speech therapists elicit verbal understanding and output, often using jokes and song to integrate emotional control of speech into the process of recovery. Physicians eye patients for opportunities to further enhance rehabilitative therapies, slight changes in gait patterns or control of an arm that might be exploited for better recovery. Personal and physical interactions coax more effort from patients and increase attempts to recover lost function. In the era of modern medicine, the human touch still sparks brain recovery.

In the morning...the clear sky appears for a moment
and it seems to me
that there has been something simpler than I could
ever believe
simpler than I could have begun to find words for...
no more hidden
than the air itself that became part of me for a while
with every breath and remained with me unnoticed
something that was here unnamed unknown -W.S. Merwin, "Just Now"2

On a Saturday afternoon the sun streams through the window on Father O'Conner's bed. He is sitting alone quietly in his chair. A greeting brings out a story and he is soon mentally back with his work in the fields, organizing the building of small houses for migrant families. He is also using his hands in 
gestures and position changes, attempting to reach out to make a point-left arm following right. He will keep this up for the entire conversation. He is rehabilitating as he recalls his life's work.

At a much younger stage in life, John is acting out his frustrations in the parallel bars in the gym. He rebels against the staff, his parents, and the white coat establishment. Yelling and kicking toward his physical therapist, she asks him if he wants to be dependent for the rest of his life. His emotionally inflamed efforts to deny her control take him twice as far in his gait therapy.

Carlos visits with Dennis, a volunteer in the unit who crashed his motorcycle several years ago. They sit together in the hallway, wheelchairs angled in a conspiratorial manner, talking closely. It is impossible to penetrate the density of this shared experience and its effect on the 2 men. Later in the afternoon Carlos gives a thumbs-up sign from his room in the first substantial recognition of anyone else in the unit.

In the small room near the gym, Eddie's sister has accompanied her to speech therapy this morning. Eddie's nonverbal command of her needs and wishes has grown extraordinarily. She laughs and sings, dodging in and out of the present and the past, holding hands with her sister as she identifies new ways to express herself.

There is something simpler than I could ever believe...something that was here unnamed unknown. In simple acts of living, patients with brain injury tell us that all of our carefully constructed views, the regulated designs for our lives and the limitations we place on our perception of this world, are possibly extraneous layers. Brain injury disrupts these layers and this is unmistakably devastating. But brain injury can also strengthen our connections to one another. The key to recovery is the realization that the world is full of mostly invisible things that connect us and do not require control or hierarchies or the placement of limitations on others. A main principle of brain repair is to establish the human connections that encourage the effort and focus to risk new movements, new gait patterns, and new ways of speaking.

On discharge, Father O'Conner goes quietly home. He is accompanied by several priest colleagues but no close crowd of supporters. He flashes that softly sanguine smile. He has seen hardship and worked to alleviate it. A life's work has been good and satisfying to this old man, and his true supporters are out in the margins of the country. This stroke is a new hardship and he will work at it as he has in the past, using experiences and stories gained from years in the fields.

Carlos leaves the unit in a tumult of youth and energy - pretty girls, young friends, close families, and a community of support. Unlike Father O'Conner, his future will require this support as it involves a transformation. This unwilling conversion from invincible youth to damaged adult will require sacrifice and accommodation, a changed perception of the future and a willingness to access personal, family, and community resources in a whole new way.

Eddie and her sister go home, where they have lived together for a longer period than most of us live at all. It is not clear that she will ever fully recover language use, but she has improved and with practice will continue to get better. In the end, her interaction with her environment and its most important element, her sister, occurs through the strong and mysterious interactions of time and genetics in a way that perhaps neurorehabilitation has simply reinforced.

Science continues to make extraordinary strides in the understanding of the injured brain and its process of reconnection and repair. New studies indicate that neural repair drugs will soon recover stunned tissues, stimulate new connections, and promote stronger brain networks. This is the promise of molecular medicine. But healing is mysterious. There is more here than Science can understand or influence.

Later in his stay John celebrated a birthday. In a room with staff and other patients, the expectant guests gathered with him to blow out the candles. A nurse asked him about his wish. "I did not wish," he replied. "I am thankful for my $15^{\text {th }}$ birthday." An ungainly and rebellious teenager had grown up, revealed in a sense of gratitude. John's road to recovery is longer, but with the promise of a young and plastic brain, his future is bright.

In the book of shadows

the first page is dark

and the second darker still,

but on the next page,

and the next, there is a flickering

as if the shadows are dancing

In the treatment of brain injury the story starts out darkly. The patient is a shadow: damaged, frightened, and withdrawn. But as physicians, therapists, and family connect, hope grows anew, recovery begins, and pages turn. And it is an appreciation of the simplest parts of ourselves, something simpler than we could ever believe, that begins personal recovery on the neurorehabilitation unit. When we can make these shadows dance, that is the art of brain repair.

\section{REFERENCES}

1. Pastan L. The Book. In: Carnival Evening: New and Selected Poems: 1968 -1998. W.W. Norton \& Company; 1999.

2. Merwin WS. Just Now. In: The Pupil: Poems. Knopf; 2002. 


\title{
Neurology
}

\author{
Molecular medicine and the art of brain repair \\ S. Thomas Carmichael \\ Neurology 2013;81;2143-2144 \\ DOI 10.1212/01.wnl.0000437307.14979.55
}

This information is current as of December 9, 2013

\section{Updated Information \& Services}

\section{Subspecialty Collections}

Permissions \& Licensing

\section{Reprints}

including high resolution figures, can be found at: http://n.neurology.org/content/81/24/2143.full

This article, along with others on similar topics, appears in the following collection(s):

\section{All Cerebrovascular disease/Stroke}

http://n.neurology.org/cgi/collection/all_cerebrovascular_disease_strok e

All Clinical Neurology

http://n.neurology.org/cgi/collection/all_clinical_neurology

\section{All Rehabilitation}

http://n.neurology.org/cgi/collection/all_rehabilitation

Brain trauma

http://n.neurology.org/cgi/collection/brain_trauma

Plasticity

http://n.neurology.org/cgi/collection/plasticity

Information about reproducing this article in parts (figures,tables) or in its entirety can be found online at:

http://www.neurology.org/about/about_the_journal\#permissions

Information about ordering reprints can be found online:

http://n.neurology.org/subscribers/advertise

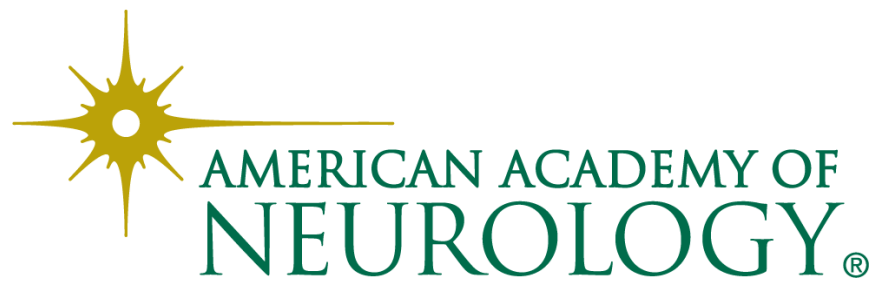

